\title{
ZNANSTVENI POSVET IN OKROGLA MIZA »EVROPSKE RAZSEŽNOSTI URBANIZACIJE« OB 70-LETNICI RED. PROF. DR. MIRKA PAKA
}

V počastitev 70-letnice rednega profesorja dr. Mirka Paka je 9. marca leta 2007 na Oddelku za geografijo potekal znanstveni posvet in okrogla miza z naslovom »Evropske razsežnosti urbanizacije«. Del prispevkov, ki so objavljeni v sedemindvajseti številki revije Dela, je bil predstavljen na omenjenem posvetu.

Slavljenca dr. Mirko Paka širši geografski javnosti verjetno ni potrebno podrobno predstavljati. S svojim pedagoškim, znanstveno-raziskovalnim, strokovnim in društvenim delovanjem se je uveljavil kot eden vodilnih slovenskih urbanih in socialnih geografov. Še posebno se odlikuje z izjemo bogato bibliografijo in mednarodno znanstveno-raziskovalno dejavnostjo. Njegov znanstveni opus obsega več kot 150 znanstvenih razprav. Osnovno raziskovalno področje dr. Mirko Paka je urbana geografija. Ukvarjal se je zlasti s problematiko socialnogeografske in funkcijske zgradbe ter preobrazbe mest. Kot eden prvih slovenskih geografov se je tako lotil problematike socialnogeografske zgradbe in socialno degradiranih območij v slovenskih mestih. V osemdesetih letih je svoje raziskave usmeril tudi v področje suburbanizacije in razvoja podeželja pod vplivom mest in urbanizacije. Kasneje se je ukvarjal zlasti z vprašanji funkcijske zgradbe in preobrazbe slovenskih mest. $\mathrm{V}$ devetdesetih letih je podrobno proučeval prostorske učinke gospodarske tranzicije na razvoj in zgradbo slovenskih mest. Še zlasti ga je zanimala preobrazba trgovine in drugih oskrbnih dejavnosti v mestih.

Znanstveni posvet, ki mu je sledila okrogla miza, je bil posvečen problematiki sodobne preobrazbe slovenskih in evropskih mest ter širših mestnih območij. Še posebno sta bili izpostavljeni tematika prostorske, socialne in funkcijske preobrazbe mest in obmestja ter vprašanje trajnostnega prostorskega razvoja urbanih območij. Referenti Miroslav Sić, Dušan Plut, Marjan Ravbar, Vladimir Drozg, Nataša Pichler Milanović in Dejan Rebernik so uveljavljeni slovenski in hrvaški geografi ter hkrati sodelavci in prijatelji dr. Mirka Paka. Častni referent je bil seveda tudi dr. Mirko Pak. Njihovi prispevki dokazujejo vitalnost in visoko strokovno raven slovenske urbane geografije, kar je v veliki meri tudi zasluga dr. Mirka Paka.

Posvet je bil razdeljen na tri vsebinske sklope: prostorski razvoj Ljubljane in Zagreba, oskrbne in terciarne dejavnosti $\mathrm{v}$ organizaciji mestnega prostora ter procesi preobrazbe in usmerjanje prostorskega razvoja mest in obmestij. Živahna strokovna razprava, ki je sledila, se je usmerila na vprašanje (ne)trajnostnega prostorskega razvoja slovenskih mest ter na iskanje ukrepov za doseganje ciljev trajnostnega razvoja urbanih območij v Sloveniji in Evropi.

Dejan Rebernik 